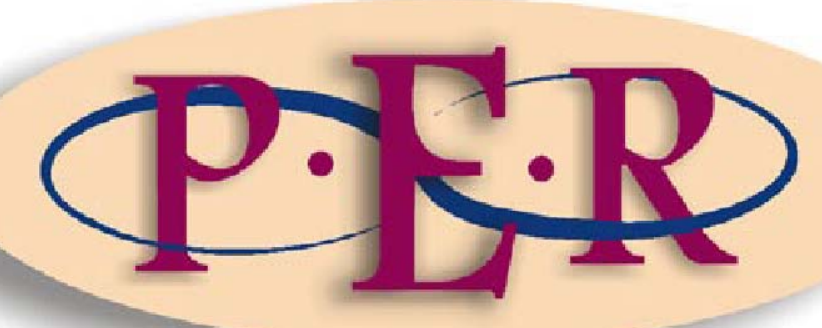

2005 VOLUME 8 No 1 


\section{SOME COMMENTS ON WATER RIGHTS IN SOUTH AFRICA}

N Gabru*

\section{Introduction}

Human life, as with all animal and plant life on the planet, is dependant upon fresh water. Water is not only needed to grow food, generate power and run industries but it is also needed as a basic part of human life. ${ }^{1}$ Human dependency upon water is evident through history, which illustrates that human settlements have been closely linked to the availability and supply of fresh water.

Access to the limited water resources in South Africa ${ }^{2}$ has been historically dominated by those with access to land and economic power, as a result of which the majority of South Africans have struggled to secure the right to water. Apartheid era legislation governing water did not discriminate directly on the grounds of race, but the racial imbalance in ownership of land resulted in the disproportionate denial to black people of the right to water. Beyond racial categorisations, the rural and poor urban populations were traditionally especially vulnerable in terms of the access to the right. ${ }^{3}$

The enactment of the Constitution of the Republic of South Africa ${ }^{4}$ brought the South African legal system into a new era, by including a bill of fundamental

* North-West University (Potchefstroom).

1 The human body needs to ingest water daily to continue functioning.

2 The DAWF White paper on a national water policy for South Africa 1997 points out in its report on Sustainable Management of Freshwater Resources in South Africa that at the population level of around 40 million, there are just over 1200 kilolitres per person per year of available fresh water. This places South Africa on the threshold of the internationally used definition of water stress.

3 Report by the DWAF in SAHRC http://www.sahrc.org.za/socio economic report main.pdf 26 Jan.

4 Constitution of the Republic of South Africa 200 of 1993, which came into effect on 27 April 1994, and which was the Interim Constitution until the enactment of The Constitution of the Republic of South Africa 108 of 1996 (hereinafter referred to as the 1996 Constitution). 
human rights. The Bill of Rights makes provision for limited socio-economic rights. ${ }^{5}$ Besides making provision for these human rights, the Constitution also makes provision for the establishment of state institutions supporting constitutional democracy. ${ }^{6}$

The Constitution has been in operation since May 1996. At this stage, it is important to take stock and measure the success in the implementation of these socio-economic rights. This assessment is important in more ways than one, especially in the light of the fact that many lawyers ${ }^{7}$ argued strongly against the inclusion of the second and third generation of human rights in a Bill of Rights. The argument was that these rights are not enforceable in a court of law and that they would create unnecessary expectations of food, shelter, health, water and the like; and that a clear distinction should be made between first generation and other rights, as well as the relationship of these rights to one anther.

It should be noted that there are many lawyers and non-lawyers who maintained that in order to confront poverty brought about by the legacy of apartheid, the socio-economic rights should be included in a Bill of Rights. The previous president, Mr Nelson Mandela, also supported this view by stating that:

The key, therefore, to the protection of any minority is to put to core civil and political rights, as well as some cultural and economic rights beyond the reach of temporary majorities, and to guarantee them as fundamental individual rights. Thirdly, we must address the issue of poverty, want, deprivation and inequality in accordance with international standard, which recognizes the indivisibility of human rights. A simple vote, without food, shelter and health care is to use first generation's rights as a smokescreen to obscure the deep underlying forces which dehumanize people. It is to create an

5 Also known as second generation rights. It should be noted that socio-economic rights were not included in the Interim Constitution, and were first introduced in the 1996 Constitution.

6 S 184 of the 1996 Constitution.

7 Eg Beatty, who warns that the notion of incorporating second and third generation rights in a constitution is in conflict with the concept of democracy, Jansen van Rensburg "Constitutional values and socio-economic rights" 3. 
appearance of equality and justice, while by implication socioeconomic inequality is entrenched. We do not want freedom without bread, nor do we want bread without freedom. We must provide for all the fundamental rights and freedoms associated with a democratic society... ${ }^{8}$

The inclusion of section 27 of the Constitution has granted each South African the right to have access to sufficient food and water ${ }^{9}$ and has resulted in the rare opportunity for South Africa to reform its water laws completely and has resulted in the enactment of the Water Services $A c t^{10}$ and the National Water Act. $^{11}$

In order to understand fully the right to water as contained in section 27 , it is necessary to distinguish between first and second generation rights which will be dealt with in section two hereunder. The justiciability of socio-economic rights is discussed in section three. In section four the constitutional implications related to water is briefly discussed. The right to water in international and comparative law is discussed in section five. The South African approach to water is considered in section six, which is followed by the concluding remarks in section seven.

\section{A distinction between first and second-generation rights}

At its most narrow, a Bill of Rights will give legal protection to the 'traditional' liberal rights to equality, personal liability, property, free speech, assembly and association - the so called civil and political or 'first generation' rights. ${ }^{12}$ These

8 Mr Nelson Mandela's opening address on the occasion of the ANC's Bill of Rights Conference, Mandela Bill of Rights for a democratic South Africa 12.

$9 \mathrm{~S} 27(1)(\mathrm{b})$ of the Constitution. A more detailed discussion on s 27 follows in s 2 hereunder.

10 Act 108 of 1997, hereinafter referred to as the Water Services Act.

11 Act 36 of 1998, hereinafter referred to as the National Water Act.

12 First-generation rights (so called because, historically they were the first rights to achieve legal recognition and protection) are based on the idea that the individual should be free of government interference when it comes to what they do in their personal and private lives and in their association with others. In this regard see De Waal, Currie and Erasmus Bill of Rights Handbook 432. 
are usually thought of as 'negative' rights, which take power away from the government by imposing a duty not to act in a certain way. ${ }^{13}$

However, the recognition that human rights and the basic social conditions of citizens are fundamentally interconnected and have encouraged attempts to include less traditional rights in modern Constitutions - socio-economic or 'second generation' rights. ${ }^{14}$

These are 'positive' rights, which impose obligations on government. Thus, rather than simply protecting members of society from the heavy hand of state power, the idea of socio-economic rights is that the state must be obliged to do whatever it can to secure a basic set of social goods for all members of society. ${ }^{15}$

In doing so, the Bill of Rights attempts to ensure that all members of society have the capacity to enjoy and participate in the rights of association, equality, political participation and expression that are traditionally protected in liberal Constitutions.

\section{The justiciability of socio-economic rights}

Attempts to make social, economic and cultural rights part of a Constitution are usually met by the argument that these rights are inherently non-justiciable, in

13 Eg the duty not to torture or the duty not to discriminate.

14 The interconnection and interdependence of the two types of rights are recognised in the principle international human rights instruments protecting socio-economic rights, the International Covenant in Economic, Social and Cultural Rights 1996 (hereinafter referred to as the ICESCR). According to the Covenant's preamble "the ideal of free human beings enjoying freedom from fear and want can only be achieved if conditions are created whereby everyone may enjoy economic, social and cultural rights, as well as civil and political rights". Second generation rights are also referred to as social, economic and cultural rights or red rights.

15 This, according to De Vos, illustrates the potentially multi-layered nature of these obligations which, according to him places the duties on the state to respect, protect and to assist and fulfill an individual's right to social security as contained in $S 7(2)$ of the Constitution. In this regard see De Vos 1995 SAPL 242-243 for a full discussion. 
other words that they are ill-suited to enforcement by the judiciary. ${ }^{16}$ Due to the fact that they are positive rights - claims by individuals and groups to the delivery of goods by government - it has been argued that their application requires the courts to direct the way in which the government distributes the state's resources and is thus beyond the scope of the judicial function. ${ }^{17}$ This is because the judiciary is usually an elite and an undemocratically appointed branch of the state. ${ }^{18}$ Therefore, so the argument goes, it lacks the democratic legitimacy necessary to decide on the division of social resources between factions, groups and communities in society. ${ }^{19}$ Even though it is usually thought to be legitimate for the judiciary to prevent the government and even the democratically-elected, representative branches of the state such as Parliament from engaging in particular practices or imposing particular duties or conditions on groups and individuals, this has traditionally been considered quite distinct from a situation in which the judiciary has the power to order these branches of state to distribute or spend public resources in a particular manner. ${ }^{20}$

The Constitutional Court discussed the nature of socio-economic rights and the problem of these enforcements in the first Certification judgment and responded to some of these arguments. The court stated: ${ }^{21}$

Nevertheless, we are of the view that these rights are, at least to some extent, justiciable. As we have stated in the previous paragraph, many of the civil and political rights entrenched in the New Constitution will give rise to similar budgetary implications without compromising their justiciability. At the very minimum, socioeconomic rights can be negatively protected from improper invasion. In the light of these considerations, it is our view that the inclusion of socio-economic rights in the New Constitution does not result in a breach of the.... [Constitutional Principles].

16 De Waal, Currie and Erasmus Bill of Rights Handbook 433-434.

17 Id 433.

18 Id 432.

19 Id 432.

20 Id 432.

21 Certification of the Constitution of the Republic of South Africa 199619964 SA 744 (CC) par 77-78. The inclusion of socio-economic rights in the Bill of Rights was objected to on the basis that the rights conflicted with Constitutional Principle VI requiring a separation of powers between the legislature, executive and judicial branches of government. 
The court makes two points. First, it questions the rigidity of the distinction drawn between socio-economic rights and civil political rights on the basis that the former entails judicial imposition of positive duties on the state, while the latter does not. Courts enforcing civil and political rights may on occasion impose positive duties on the state. ${ }^{22}$

Secondly, the court confirms that the socio-economic rights are justiciable. As to the extent of their justiciability, the court indicated that the rights can, at least, be "negatively protected from improper invasion". The language used here makes it clear that negative protection is merely the minimum extent to which the rights can be judicially protected and does not exhaust the possibilities of justiciability.

Negative protection, in the usual form of judicial protection given to civil and political rights and applied to socio-economic rights, means that a court can prevent the state from infringing on the socio-economic rights directly. The right to health care, sufficient food and water, social security and to basic education may not be subjected to what has been termed "deliberately retrogressive measures". ${ }^{23}$ A deliberately retrogressive measure is one which has the effect of denying individuals their existing access to water, food, or housing, or preventing them from using whatever resources they have at their disposal to satisfy their water, food and housing needs. A clear example is the arbitrary eviction of squatters without the provision of alternative accommodation. The state must not only refrain itself ${ }^{24}$ from interfering in the enjoyment of socioeconomic rights, but must also take steps to prevent interference by private individuals. $^{25}$

22 Eg when applied to the right to access to housing in terms of $s 26$, it requires the state to assist individuals in making it possible for them to realise the right. It could include steps to organise access to home loans for low-income households and the provision of sites for informal settlement. It does not, however, entitle the state to provide houses on demand. This issue was discussed by the court in Grootboom v Oostenberg Municipality 20003 BCLR 277 (C); Government of the Republic of South Africa v Grootboom 200011 BCLR $1169(\mathrm{CC})$.

23 UN Committee on Economics, Social and Cultural Rights, General Comment 31994 par 9.

24 Known as a duty to respect. S 7(2) of the Constitution.

$25 \mathrm{Eg}$ by legislative measures prohibiting arbitrary evictions by private individuals or protecting security of tenure. Known as a duty to protect. S 7(2) of the Constitution. 
The state's obligation does not, of course, end with the duty to refrain from interference with the enjoyment of the socio-economic rights. The rights have an additional positive dimension. Taking positive steps directed towards fulfilling these rights can only adequately fulfil the rights of access to housing, healthcare, food, water and social security. ${ }^{26}$

In international law, it is generally recognised that the positive component of socio-economic rights requires two forms of action from the state. The first is that the state must create a legal framework that grants individuals the legal status, rights and privileges that will enable them to pursue their rights. The second requires the state to implement measures and programmes designed to assist individuals in realising their rights. ${ }^{27}$

This distinction is illustrated by the government's current land reform programme. The state is obliged by the socio-economic right in section 25(5) to

...take reasonable legislative and other measures, within its available resources, to foster conditions which enable citizens to gain access to land on an equitable basis.

The programme that has been embarked upon corresponds to the two forms of compliance with the positive dimension of socio-economic rights outlined above. The first is to give legal protection to particularly vulnerable groups and individuals through the creation of statutory rights protecting them against arbitrary eviction. ${ }^{28}$ The second set of measures is more direct, involving land redistribution programmes and the making available of a land acquisition subsidy to households for the purpose of acquiring land or housing. ${ }^{29}$ Another example is The Government of the Republic of South Africa v Grootboom and

26 Known as the duty to realise. S 7(2) of the Constitution.

27 De Vos 1997 SAJHR 83-86.

28 Land Reform (Labour Tenants) Act 3 of 1996; Extension of Security of Tenure Act 62 of 1997.

29 The subsidy administered by the Department of Land Affairs is known as the Settlement Land Acquisition Grant and currently is an amount of R15 000 per household. 
Others. $^{30}$ In the judgment of the court a quo, ${ }^{31}$ dealing with sections 26 and 28(1)(c) of the Constitution, it was noted that the Constitution obliges the state to act positively to ameliorate the plight of the hundreds of people living in deplorable conditions throughout the country. It must provide access to housing, healthcare, sufficient food and water, and social security to those unable to support themselves and their dependants.

The positive dimension of the socio-economic rights is qualified by the use of the phrase 'employed' in section 26(2) and section 27(2) obliging the state to only those steps "within its available resources, to achieve this aggressive realization of the right". The meaning of this qualification has been interpreted as follows by the Constitutional Court: ${ }^{32}$

What is apparent from these provisions is that the obligations imposed on the state by section 26 and section 27 in regard to access of housing, health care, food, water, and social security are dependent upon the resources available for such purposes, and that the corresponding rights themselves are limited by reason of the lack of resources. Given this lack of resources and the significant demands on them that have already been referred to, an unqualified obligation to meet these needs would not presently be capable of being fulfilled.

This passage suggests that the positive dimension of the socio-economic rights is 'realised' or fulfilled through state action 'progressively' or over a period of time. ${ }^{33}$ The rights are limited by the qualifications that they are only available to the extent that state resources permit. ${ }^{34}$ In the absence of available state resource, the failure of the state to address socio-economic rights is, therefore, not a violation of the right. However, should resources become available, it

30 The Government of the Republic of South Africa v Grootboom 200011 BCLR 1169. Hereinafter referred to as Government of South Africa v Grootboom.

31 Grootboom v Oostenberg Municipality 20003 BCLR 277 (C). Hereinafter referred to as Grootboom v Oostenberg Municipality.

32 Soobramoney $v$ Minister of Health (KwaZulu-Natal) 19981 SA 765 (CC) par 11. Hereinafter referred to as Soobramoney.

33 De Waal, Currie and Erasmus Bill of Rights Handbook 423. See also Jansen van Rensburg 1999 De Jure 294.

34 De Waal, Currie and Erasmus Bill of Rights Handbook 423. See also Jansen van Rensburg 1999 De Jure 294. 
would be difficult for the state to justify its failure to devote those resources to the fulfilment of the rights. It is submitted that this indicates that the positive dimension of the socio-economic rights can be described as a right to have the state justify its use of its resources to its citizens. This submission has been confirmed by the treatment of the Constitutional Court for the justifications of the policies advanced by the provincial health authorities in Soobramoney.

The Constitutional Court found that the Department of Health in KwaZulu-Natal did not have sufficient funds to cover the cost of services being provided to the public. In 1996, the Department overspent its budget by 152 million rand and it was anticipated that the overspending would increase to 700 million in 1997 , unless a serious cutback to the services that the hospital provides was made. It was noted by the court that there are many more patients suffering from chronic renal failure than there are dialysis machines to treat such patients. It was further noted by the court that the shortage of such machines is a nation wide problem and state resources are stretched in all renal clinics throughout the country.

Due to these factors, guidelines have been established to assist the persons working in these clinics to make the agonising choices that have to be made in deciding who should receive treatment and who not. These guidelines were applied by the hospital in the Soobramoney. ${ }^{35}$

The court stated that the courts in South Africa would be slow to interfere with rational decisions taken in good faith by the political organs and medical authorities whose responsibility it is to deal with such matters.

The language of 'progressive realisation' and the 'available resources' qualifications are employed in the international instruments, where they are understood to grant the state a margin of discretion in selecting the means for achieving socio-economic rights. ${ }^{36}$ However, it is clear that the qualification 
does not mean that the state is simply left to its own devices in choosing whether and how to implement the rights. The following principles have emerged from international practice:

The fact that the full realization of socio-economic rights can only be achieved progressively does not alter the obligations on the state to take those steps that are within its power immediately and other steps as soon as possible. The burden is on the state to show that it is making progress toward full realization of the rights. ${ }^{37}$

Resource scarcity does not relieve states of what the International Committee on Economic, Social and Cultural Rights ${ }^{38}$ terms 'core minimum obligations'. ${ }^{39}$ Violations of socio-economic rights will occur when the state fails to satisfy minimum essential levels of each of the rights, or fails to prioritise its use of its resources so as to meet its core minimum obligations. These core minimum obligations apply unless the state can show that its resources are 'demonstrably inadequate' to allow it to fulfil its duties. However, even when resources are scarce, the obligation remains on the state to 'strive to ensure the widest possible enjoyment of the relevant rights under the prevailing circumstances'. ${ }^{40}$

It is important to distinguish the inability from the unwillingness of a state to comply with its obligations. The fact that obligations are to be realised progressively does not mean that the state may postpone its obligations to some distant or unspecified time in the future. A state claiming that it is unable to carry out its obligations because of resource scarcity is under a burden of proving that this is the case. ${ }^{41}$

37 This accords with the Constitutional Court in Soobramoney. While the state has a margin of discretion in determining which measures it will implement and how it will utilise its resources, it must show that it is exercising its discretion rationally and in good faith. See in this regard De Waal, Currie and Erasmus Bill of Rights Handbook 424-425.

38 This is the monitoring committee in terms of the ICESCR.

39 UN Committee on Economics, Social and Cultural Rights, General Comment 31994 par 10. See also De Waal, Currie and Erasmus Bill of Rights Handbook 425.

40 De Waal, Currie and Erasmus Bill of Rights Handbook 425.

41 Maastricht Guidelines on Violation of Economic Social and Cultural Rights 1997 par 13 (reprinted in Urban Morgan Institute for Human Rights 1998 Human Rights Quarterly 691). 


\section{The constitutional implications related to the right to access to water}

The people of South Africa have agreed to heal the divisions of the past and establish a society based on democratic values, social justices and fundamental human rights. This can be gauged from the preamble of the Constitution which declares:

We, the people of South Africa, recognise the injustices of our past, and believe that South Africa belongs to all who live in it, united in our diversity.

Section 27 of the Constitution guarantees every person the right to have access to sufficient food and water. This right is also an indispensable element of other rights, particularly the right to adequate food ${ }^{42}$ (or nutrition), the right to health care $^{43}$ and a clean and/or healthy environment ${ }^{44}$ and water conservation. ${ }^{45}$ Other human rights such as housing ${ }^{46}$ and education ${ }^{47}$ may also protect specific aspects of the right to water.

In order to understand the nature and extent of a person's right to have access to water, as guaranteed in section 27 , an in depth analyses of this section follows hereunder.

\subsection{Section 27 of the Constitution}

Section 27 provides for a "right to have access to" health care, food, water and social security. The nature of the obligation imposed by section 27 is not, 
however, an unqualified obligation of the state duty or duty to provide health care, food, and water on demand.

First, the 'access to' qualification ${ }^{48}$ means that the state owes a duty only to those sections of the population without the means to ensure access to health care, food, water and social security. ${ }^{49}$ Those who have means already have access to health care, food, water and social security, since they can afford it, and thus cannot claim it from the state. ${ }^{50}$ Section $27(2)$ provides that the state 'must take reasonable legislative and other measures, within its available resources', to achieve the progressive realisation of each of these rights.

Reasonableness provides the yardstick against which the measures must be tested. The 'measures' will include national, provincial or local government legislation as well as administrative measures. In the Government of South Africa $v$ Grootboom, the court, in its analysis of section 26 stated that it is not possible to determine the minimum threshold for the progressive realisation of the right without first identifying the needs and opportunities for the enjoyment of such a right. ${ }^{51}$ The court then continued to identify the real question in terms of the Constitution to be whether the measures taken by the state to realise the right afforded by section 26 are reasonable. In its judgment, the court concluded that, at the date of the launch of the application, the state was not meeting the obligation imposed on it by section 26(2) of the Constitution. In particular, the programmes adopted by the state did not comply with the requirements of section 26(2) as no provision was made for the relief to the categories of people most desperately in need. ${ }^{52}$

The Constitution does not provide explicit guidance as to the meaning of 'sufficient' water, in particular the quantity and quality of water each individual is entitled to access, and the meaning is yet to be considered by a South African

48 Rather than the right to.

49 See in this regard Government of South Africa v Grootboom par 21, 24, 31, 35 and 38.

50 See in this regard Liebenberg "Socio-economic rights" 41-44.

51 Government of South Africa v Grootboom par 32.

52 Id par 69. 
court. However, "basic water supply" is defined in section 2 of the Compulsory National Standards and Measures to Conserve Water Regulations ${ }^{53}$ as a minimum quantity of potable water of twenty-five litres per day accessible within two hundred metres. Sufficient food and water are components of an adequate standard of living, ${ }^{54}$ which has been linked to necessities of life in "accordance with the prevailing cost and standard of living in the country concerned". ${ }^{55}$

The constitutional property clause, which commences with the general rule that "no one may be deprived of property except in terms of law of general application", ${ }^{56}$ also states that "property is not limited to land", ${ }^{5}$ implying that water rights could be regarded as an incorporeal property right. ${ }^{58}$ The same section also states that the public interest includes not only the nation's commitment to land reform but also "to reforms to bring about equitable access to all South Africa's natural resources", which includes water. ${ }^{59}$

In terms of Schedule 4 Part B of the Constitution, local government is tasked with providing water and sanitation services including portable water supply systems and domestic wastewater and sewage disposal systems. These obligations are concretised in the Municipal Systems Act 32 of $2000 .^{60}$ It should be noted that fundamental rights and freedoms are not absolute, and a discussion pertaining to the limitations of such rights is, therefore, justified.

\subsection{Fundamental right to have access to water and its limitations}

As stated above, fundamental rights and freedoms are not absolute. Their boundaries are set by the rights of others and by the legitimate needs of society. Generally, it is recognised that public order, safety, health and democratic values justify the imposition of restrictions on the exercise of

53 GG 223558 June 2001.

54 See in this regard Eide "Right to an adequate standard of living".

55 See in this regard the discussion in Samuel Fundamental social rights 316.

56 S 25(1) of the Constitution.

57 S 25(4)(b) of the Constitution.

58 Klug 1997 HRCLJ 5- 6.

$59 \mathrm{~S} 25(8)$ of the Constitution.

60 A full discussion of this act falls beyond the scope of this article. 
fundamental rights. ${ }^{61}$ In the Constitution, a general limitation clause ${ }^{62}$ sets out specific criteria for the restriction of the fundamental rights in the Bill of Rights. ${ }^{63}$

In Government of the Republic of South Africa v Grootboom, the Constitutional Court made no reference to the limitation clause. ${ }^{64}$ Despite finding that the state's housing programme fell short of the obligations imposed by section 26(2) of the Constitution, the possibility of justifying these shortcomings in terms of section 36 was not canvassed. One reason for leaving section 36 out of the account lies in the difficulty of applying the 'two-stage' analysis ${ }^{65}$ of a right and justification for the limitation of that right to section $27 .{ }^{66}$ This is because one of the principle criteria justifying the limitation of rights in the general limitation clause ${ }^{67}$ has been included in the demarcation of this right. Applying the limitation clause to an infringement of the socio-economic rights would, therefore, put a court in the self-defeating position of arguing the reasonableness of a measure that has already been found to lack reasonableness. ${ }^{68}$

61 Erasmus "Limitations and suspension" 629.

62 S 36 of the Constitution.

63 For a detailed discussion on the limitation clause refer to De Waal, Currie and Erasmus Bill of Rights Handbook 144-165.

$64 \mathrm{~S} 36$ of the Constitution.

65 A full discussion on the 'two-stage' approach falls beyond the scope of this article. For a detailed discussion refer to De Waal, Currie and Erasmus Bill of Rights Handbook 144165. See also $S$ v Zuma 19954 BCLR 401 (CC), where the court expounded on the 'twostage' approach in detail.

66 Similar difficulties of application of s 36 and the 'two-stage' analysis to rights such as s 9 and 25 qualified by terms that approximate the criteria for justifiable limitations have been discussed in De Waal, Currie and Erasmus Bill of Rights Handbook in ch 7, 9 and 25.

67 Reasonableness.

68 Another reason why the limitation clause would have been inapplicable in Government of South Africa $v$ Grootboom is the absence of a law of general application authorising the limitation of the s 26(2) right. The problem with the state's programme was the absence of legislative or other measures providing for emergency relief. 


\section{The right to water in international and comparative law}

\subsection{A discussion}

The most important international instrument relating to socio-economic rights is the ICESCR, which has been ratified by approximately one hundred and thirty states. ${ }^{69}$ The substantive rights that are recognised by the Covenant are: to work and to just and favourable conditions of work, rest and leisure; to form and join trade unions and to strike; to social security; to special protection for the family, mothers and children, an adequate standard to living including food, clothing and housing, physical and mental health care, and to scientific and cultural life. Thus it is clear that the right to water or to access to water does not enjoy explicit recognition at international level and is mentioned by name in only a few international documents. Where the right is explicitly mentioned, it is restricted in most cases to access to water for drinking and other domestic purposes. Nevertheless, other internationally recognised human rights, for example food and a healthy environment, may entitle an individual to water for other purposes. The close link between water, food (nutrition), health and hygiene, render international documents that protect these rights relevant.

Article 11(1) of the ICESCR proclaims:

The state parties to the present Covenant recognises the right of everyone to an adequate standard of living for himself and his family, including the right to adequate food, clothing, housing...

The ICESCR Committee boldly interpreted the right to an adequate standard of living and the right to health, ground as an independent right to water for

69 South Africa signed the Covenant in 1994, but has not yet ratified it. Other Conventions protecting socio-economic rights ratified by South Africa are the Convention on the Elimination of all forms of Discrimination Against Women 1979, hereinafter referred to as CEDAW; The Convention of the Rights of the Child 1995; and the African Charter on Human Peoples' Rights 1981. The influence of the ICESCR on the drafters of the Constitution is evident in the use in the latter of concepts such as 'progressive realization' and the state's duty to take "reasonable legislative and other measures within its available resources", drawn from a 2 of the Covenant. See also Liebenberg "Socio-economic rights" 41-44. 
personal use and domestic uses. General Comment 15 provides an extensive interpretation of the implications of the right to water for state parties in terms of the duties incumbent upon them to realise the right. The committee stated:

The right to water clearly falls within the category of guarantees essential for securing an adequate standard of living, particularly since it is one of the most fundamental conditions for survival.

Article 12 of ICESCR provides for the right of everyone to the highest attainable standard of health. Under article 12(2)(b) state parties to the treaty must aim to improve all aspects of environmental and industrial hygiene. This duty

...encompasses taking steps on a non-discriminatory basis to prevent threats to health from unsafe and toxic water conditions.

States are also obliged to aim for the prevention, treatment and control of epidemic, endemic, occupational and other diseases. In an earlier General Comment the committee stated that the underlying determinants of the right to health include potable water. ${ }^{70}$

Article $14(2)(h)$ of CEDAW obliges state parties to ensure to rural women the right to enjoy adequate living conditions, particularly in relation to housing, sanitation, electricity and water supply, transport and communications.

Article 24 of $C R C$ obliges state parties to implement children's rights to health by taking appropriate measures to combat disease and malnutrition within the framework of primary health care. It specifically requires that readily available technology should be applied and that adequate nutritious food and clean drinking water should be provided, taking into consideration the dangers and risks of environmental pollution.

International humanitarian law provides extensive protection during armed conflict with respect to water. Sufficient drinking water is to be supplied to 
prisoners of war and other detainees. They are to be provided with shower and bath facilities as well as water, soap and other facilities for their daily personal toilet and washing requirements. ${ }^{71}$ The Additional Protocols of 1977 also prohibit the destruction of

...objects indispensable to the survival of the civilian population, such as food, agricultural areas for the production of food, crops, livestock, drinking water installations and supplies and irrigation works. $^{72}$

A number of international conferences on environmental issues and/or water have taken place, recognising and affirming the right of all human beings to have access to clean water and sanitation at an affordable price. These include the Preamble to the Mar del Plata Declaration of the 1977 United Nations Water Conference, the 1991 UN Principles of Older Persons and the 1992 Dublin Statement on Water and Sustainable Development. ${ }^{73}$ Action programmes adopted by states at such conferences, such as 1992 Agenda 21 and the Programme of Action of the 1994 International Conference on Population and Development, have likewise included the right to water.

Turning to the regional level, the European Social Charter does not explicitly refer to a right to nutrition or water. Article 11 states that contracting parties should, either directly or in co-operation with public or private organisations, inter alia remove as far as possible the causes of ill-health and prevent as far as possible epidemic, endemic and other diseases.

71 See a 21, 25, 29, 46 and 85 Geneva Convention III; a 89 and 127 Geneva Convention IV; and a 5 Additional Protocol II.

72 See a 54 Additional Protocol I and a 14 Additional Protocol II.

73 The statement was issued by government-designated experts from a hundred countries and representatives of eighty international, intergovernmental and non-governmental organisations at the International Conference on Water and the Environment. 
The Committee of Ministers of Member States of the Council of Europe have recognised that "everyone has the right to a sufficient quantity of water for his or her basic needs". ${ }^{74}$

Article 11 of the American Convention of Human Rights in the Area of Economic, Social and Cultural Rights of 1988 states that:

...everyone shall have the right to live in a healthy environment and to have access to basic public services.

Article 16(2) of the African Charter on Human and Peoples' Rights proclaims that state parties to the Charter must take the necessary measures to protect the health of their people. Access to water is not explicitly mentioned, but the obligation to protect the health and environment of its citizens would imply that a state party must ensure that its subjects enjoy basic water and sanitation services.

The African Commission on Human and Peoples' Rights has previously derived rights such as food and housing form the right to health and other Charter rights. ${ }^{75}$ In Free Legal Assistance Group, Lawyers' Committee for Human Rights, Union Interafricaine des Droits de l'Homme, Les Témoins de Jehova $v$ Zairre, ${ }^{76}$ the commission held that:

...the failure of the government to provide basic services such as safe drinking water and electricity and the shortage of medicine... constitutes a violation of article $16 .^{77}$

74 Council of Europe http://www.asil.org/ilib/ilib0413.htm 23 Mar at par 5 of the recommendation of the Committee of Ministers to Member States of the European Charter on Water Resources.

75 Free Legal Assistance Group v Zaïre ACHPR Comm No 25/89, 47/90, 56/91, 100/93 (1995) Communication 155/96, SERAC and CESR v Nigeria ACHPR Comm No 155/96, $15^{\text {th }}$ Annual Activity Report.

76 Id Comm No 25/89, 47/90 \& 56/91, $199 / 93$ (joined), $9^{\text {th }}$ Annual Activity Report.

77 The right to health. 
Article 14(1) of the African Charter on the Rights and Welfare of the Child provides that every child has the right "to enjoy the best attainable state of physical, mental and spiritual health". Article 14(2)(c) explicitly stipulates that:

State parties to the present Charter shall undertake to pursue the full implementation of this right and in particular shall take measures to ensure the provision of adequate nutrition and safe drinking water.

Article 15 of the Protocol to the African Charter on the Rights of Women in Africa states that:

State parties shall ensure that women have the right to nutritious and adequate food. In this regard, they shall take appropriate measures to:

(i) provide women with access to clean drinking water, sources of domestic fuel, land, and the means of producing nutritious food;

(ii) establish adequate systems of supply and storage to ensure food security.

\subsection{International and foreign law - what does the Constitution say?}

Section 39(b) states that when interpreting the Bill of Rights, a court, tribunal or forum must consider international law. Therefore, it can be said that section 39(b) places an obligation on a court, tribunal or forum to consider international law when interpreting the Bill of Rights. Section 39(c) states that when interpreting the Bill of Rights, a court, tribunal or forum may consider foreign law.

In the case $S v$ Makwanyane and Another ${ }^{78}$ the court held that having regard to international law does not necessarily mean following it. Customary international law is international law, which fulfils the requirements of usus ${ }^{79}$ 
and opinion iuris. ${ }^{80}$ In this case the court made a distinction between binding and non-binding law and stating that they are both included in public international law and may both be used as tools of interpretation. ${ }^{81}$ Dugard remains of the opinion that a practice which has persistently been objected to, is not a customary rule. ${ }^{82}$ It should be noted that in order for a treaty to be binding on South Africa, it has to be signed, ratified and enacted into law by national legislation. ${ }^{83}$ The fact that South Africa is in the process of ratifying the ICESCR places an international duty on the state to realise progressively socioeconomic rights contained in the Covenant. The state thus has not only a constitutional but also an international obligation to realise social security rights progressively. ${ }^{84}$

\subsection{Supervisory institutions}

Section 184 of the Constitution describes the functions of the commission. The South African Human Rights Commission provides for a peculiar monitoring and enforcement mechanism in order to ensure governmental compliance with the fundamental rights. In Government of South Africa v Grootboom, the South African Human rights Commission and the Community Law Centre of the University of the Western Cape were admitted as amici curae in the appeal. The South African Human Rights Commission thus has a key role to play in monitoring and enforcing the implementation of social security rights. Section 184 is in many ways similar to international reporting systems. Supervisory bodies such as the United Nations Committee on Economic, Social and Cultural Rights can provide a model for comparison to suggest guidelines about the type of information that is required and the manner in which it should be presented. ${ }^{85}$

80 General acceptance of an obligation to be bound. See in this regard Dugard International Law 28.

81 Government of South Africa v Grootboom par 26.

82 Dugard International law 54.

83 S 231(2) and (4) of the Constitution.

84 Also refer to Dugard International law.

85 See also Liebenberg "Socio-economic rights" 41-44. 


\section{The South African scene}

As stated in section one above, the inclusion of section 27 of the Constitution has granted each South African the right to have access to sufficient food and water $^{86}$ and has resulted in the rare opportunity for South Africa to reform its water laws completely, and has resulted in the enactment of the Water Services Act and the National Water Act. A brief discussion of these two acts follows.

\subsection{The National Water Act}

The National Water Act 36 of 1998 was promulgated on 1 October $1998 .^{87}$ It is submitted that the enactment of the Act reflects the new democratic spirit by giving effect to the constitutional right of access to water. ${ }^{88}$ The purpose of the Act is explicitly stated in section 2 as:

... to ensure that the nation's water resources are protected, used, developed, conserved, managed and controlled. ${ }^{89}$

It is for this reason that the Act declares the national government to be the public trustee of the nation's water resources and prioritises socio-economic and environmental needs. ${ }^{90}$

The Act repealed the Water Act 54 of 1956, which essentially consolidated water law as it had developed during the history of colonial expansion and sets the scene for a new water dispensation in South Africa. It has also repealed about a hundred other acts, which previously cluttered the water statute books and therefore, the National Water Act must be read with only one other statute,

86 S 27(1)(b) of the Constitution.

87 Procl R95 of 1998.

88 S 27 elaborated on above, stated that everyone has the right to access to water.

89 This phrase is used extensively throughout the Act.

$90 \mathrm{~S} 3(1)$ states that the national government is the public trustee of the nation's water resources. 
namely the Water Services Act. In doing so, the National Water Act consolidates water law into a unified whole. ${ }^{91}$

It is submitted that the National Water Act, which is administered by the Department of Water Affairs and Forestry, must be seen as giving life to section 27(2) of the Constitution.

An important feature of the National Water Act is that it emphasises public participation in the various norms and procedures which it lays down, and a significant innovation is that the National Water Act includes specific measures providing for community involvement and gender representation in water management institutions. ${ }^{92}$ It is submitted that the 'public involvement policy' is further justified and emphasised by the fact that prior to the enactment of the National Water Act, an extensive public participation programme initiated by the Department of Water Affairs and Forestry which led to the culmination of the White Paper on a National Water Policy for South Africa, ${ }^{93}$ tabled a set of 28 "Fundamental Principles and Objectives for a new Water Law of South Africa". These principles provided the basis for the National Water Act. ${ }^{94}$

It should be noted that the National Water Act shifts the emphasis from the traditional approach of 'supply management' which is concerned with managing the supply of water through the building of dams, et cetera, towards 'demand management' which seeks to conserve the nation's water resources by lessening demand through pricing mechanisms and other innovative means. This shift will be implemented through the financial provisions provided for in

91 Schedule 7 of the National Water Act. It should, however, be noted that certain sections of the Water Act 54 of 1956 have been specifically preserved.

92 An example of this can be found in ch 8 of the National Water Act, which provides for community involvement in water use at the local level. Another example is s 81(10)(b) of the Act, which refers to sufficient gender representation on the Boards of Catchment Management Agencies.

93 White paper on a national water policy for South Africa 1997.

94 Appendix 1 to White paper on a national water policy for South Africa 1997 at 35. 
Chapter five of the National Water Act. The Minister is hereby empowered to establish a pricing strategy and to levy charges for water use. ${ }^{95}$

The National Water Act incorporates environmental considerations in various ways, but generally it does so by adapting the legal regime to the realities of the hydrological cycle, by introducing the pioneering concepts of a reserve and by focusing water resource management around catchment management agencies. $^{96}$

As stated above, the National Water Act must be read in conjunction with the Water Services Act and, therefore, a brief discussion of the Water Services Act follows.

\subsection{The Water Services Act}

The public consultation exercise, which culminated the White Paper on Water Supply and Sanitation Policy, ${ }^{97}$ preceded the Water Services Act. This act recognises the right to access a basic water supply. This is stated explicitly as one of the main objectives of the Water Services Act. ${ }^{98}$ In the Water Services $A c t$, the duty on the part of the Water Services Authorities to provide access to water services is clearly spelled out in section 11(1) as follows:

Every water service authority has a duty to all consumers or potential consumers in its area of jurisdiction to progressively ensure efficient, affordable, economical and sustainable access to water services.

While this duty is subject to a number of conditions including inter alia the availability of resources and the duty of consumers to pay reasonable charges, ${ }^{99}$ the Water Services Act entrenched this duty by stating in section

95 S 56 and 57 of the National Water Act. A full discussion relating hereto falls beyond the scope of this article.

96 Environmental considerations fall beyond the scope of this article. For a more in depth discussion on this refer to Glazewski "New water law" 531-537.

97 White Paper on Water Supply and Sanitation Policy 1994.

$98 \mathrm{~S} 2$ of the Water Services Act.

$99 \mathrm{~S} 11(2)$ of the Water Services Act. 
11(4) that a water services authority may not unreasonably refuse to give access to water services to a consumer or potential consumer in its area of jurisdiction. Further in section 11(5), the act states that in emergency situations a water service authority must take reasonable steps to provide basic water supply and basic sanitation services to any person within its jurisdiction and may do so at the cost of that authority.

\subsection{Other legislative measures}

The Municipal Systems Act ${ }^{100}$ provides the legislative framework for the service delivery responsibilities of local governments. Section 73(1) of the Act instructs municipalities to ensure that:

All members of the local community have access to at least the minimum level of basic municipal services.

The enactment of this act must be interpreted as a legislative measure taken to realise the right to have access to sufficient water. ${ }^{101}$

The promulgation of regulations to set compulsory national standards and measures to conserve water and to set norms and standards in respect of tariffs for water services, in terms of section 9(1) and 10(1) of the Water Services Act, should also be seen as a legislative measure taken to realise the right to have access to sufficient water.

\subsection{Case Law}

Resident of Bon Vista Mansions v Southern Metropolitan Local Council ${ }^{102}$ and Manqele $v$ Durban Transitional Metropolitan Council ${ }^{103}$ indicates the existing discontention with the water services in South Africa.

100 Local Government: Municipal Systems Act 32 of 2000. Hereinafter referred to as the Municipal Services Act.

$101 \mathrm{~S} 27$ of the Constitution.

102 Resident of Bon Vista Mansions v Southern Metropolitan Local Council 20026 BCLR 625 (W). 
In the Resident of Bon Vista Mansions v Southern Metropolitan Local Council, the applicants sought interim relief on an urgent basis for the reconnection of their water supply. The applicants relied directly on the Constitution in this matter. The court held that the obligation to respect existing access entails that the state may not take any measures that result in preventing such access. By disconnecting the water supply, the council had prima facie breached the applicant's existing rights, the court held that a prima facie violation of a local council's constitutional duty occurs if a local authority disconnects an existing water service, and that such disconnection, therefore, requires constitutional justification.

The discontention with regards to water services had to be considered by the court in Manqele v Durban Transitional Metropolitan Council. The applicant, an unemployed woman who occupied premises with seven children, sought a declaratory order that the discontinuation of water services to the premises was unlawful. She argued that the by-laws in terms of which the water services were disconnected were ultra vires the Water Services Act. The applicant relied on her right to a basic water supply as referred to in the Act and did not rely on the Constitution. The respondent argued that as no regulations have been promulgated to give meaning to the right to 'basic' water supply, the right has no content. The court agreed with the respondent's argument. It is submitted that the court would have been confronted with assessing the scope of the right to basic water supply under the Water Services Act had the constitutional argument been advanced by the applicant.

\subsection{Governmental policies}

The manner in which the right has been framed makes it clear that the state is not obliged to provide every inhabitant of South Africa with a free water supply. The state's duty towards those individuals who have the ability to pay for water 
services entails that the state must create the conditions and opportunity to ensure that those individuals have 'access' to sufficient water. Sections 11(4) and (5) of the Water Services Act, as outlined above, suggest that where individuals are unable to pay for water services, authorities are obliged to provide such access.

The White Paper on National Water Policy points out that between twelve and fourteen million South Africans did not at the time of publication have access to safe water and over twenty million are without adequate water and sanitation. The Department of Water Affairs and Forestry, has made significant strides in redressing this state of affairs. The current policy of the Department of Water Affairs and Forestry entails the provision of six thousand litres of water for every household per month without charge. ${ }^{104}$ The National Water Act covers water for other purposes, such as livelihoods, and a system of licences has been established for securing access to water. ${ }^{105}$

The Department also has introduced programmes such as "Working for Water". The primary aim of the Working for Water programme is to increase the water supply by eliminating alien vegetation. In doing so, the programme has provided much-needed employment and secondary spin-offs such as the establishment of a poverty relief fund. ${ }^{106}$ The Department also initiated the Free Basic Water Policy ${ }^{107}$ during December 2000. The primary intention of the FBW Policy is to alleviate poverty by ensuring that no one is denied access to basic water supply. ${ }^{108}$ The programme is primarily targeting the poor, these being those people living in rural areas, people living in informal settlements, low

104 Known as the Free Basic Water Policy. (Hereinafter referred to as FBW Policy).

105 The responsible licensing authority must inter alia take into account factors such as the need to redress the results of past racial and gender discrimination, efficient and beneficial use of water in the public interest and the resource quality objectives of the water resource. Conditions may be attached to a license inter alia relating to the protection of the water resource, water management, return flow and discharge of disposal of waste.

106 The Working for Water Programme 1998.

107 DWAF http://www.dwaf.gov.za/freebasicwater/ 23 Mar.

108 The $F B W$ Policy is aimed at assisting the marginalised and vulnerable groups through cross-subsidisation of their water supply by the wealthier higher consumers or by the fiscus. See in this regard the SAHRC http://www.sahrc.org.za/4th esr chap 9.pdf 1 Feb at 410. 
income groups and those racial groups disadvantaged by past discriminatory laws and practices. To date the Department reports that $57 \%$ of South Africans are receiving free basic water and that 214 of the 309 municipalities are already implementing the FBW Policy.

\section{Conclusion}

During the first 10 years of democracy a great deal has been learned with regards to fundamental rights and a significant headway has been made in South Africa. The Constitution clearly spells out in the preamble to and in the Bill of Rights, the country's commitment to the provision of socio-economic rights.

The inclusion of economic, social, and cultural rights as directly enforceable rights in South Africa's Constitution, signals a decisive break with the idea that the Bill of Rights is only a shield which protects citizens against government interference. This means that the Bill of Rights will require judges, lawyers and academics to scrutinise and reject many of the accepted practices and assumptions in relation to judicial review.

No judgment of the Constitutional Court deals, in a concrete form, with the right to have access to water within the context of section 27(1) of the Constitution. However, it suffices to indicate the content of the right. The right protected under section 27 is the right to have access to sufficient food and water. This means that the state may not deny anyone access to sufficient water. The availability of access to water will depend on the availability of the resources at the disposal of the state.

The Constitutional obligation of the state in terms of this section is to take reasonable legislative and other measures within its available resources to achieve the progressive realisation of this right. Therefore, it is submitted that the enactment of the Water Services Act and the National Water Act should be considered as a step taken in the right direction by the legislature. 
In Grootboom the court stated:

Socio-economic rights are expressly included in the Bill of Right; they cannot be said to exist on paper only. Section 7(2) of the Constitution requires the state to 'respect, protect and fulfil the rights in the Bill of Rights' and the courts are constitutionally bound to ensure that they are protected and fulfilled. The question is, therefore, not whether socio-economic rights are justiciable under our Constitution, but how to enforce them in a given case. ${ }^{109}$

Whether the Bill of Rights fulfils its true potential will depend, to a large extent, on whether judges will discover in themselves the courage and imagination to engage in these challenges. Those judges willing to take on the challenge will find a wealth of writing and opinion in the field of intentionally human rights to assist them in their endeavour.

109 Government of the Republic of South Africa v Grootboom 2000 (11) BCLR 1169 (CC) at 1184. 


\section{Bibliography}

De Vos 1995 SAPL 242-243

De Vos "The economic and social rights of children and South Africa's transitional Constitution" 1995 SAPL 242-243

De Vos 1997 SAJHR 83-86

De Vos "Pious wishes or directly enforceable human rights? Social and economic rights in South Africa's 1996 Constitution" 1997 (13) SAJHR 8386

De Waal, Currie and Erasmus Bill of Rights Handbook

De Waal J, Currie I and Erasmus G The Bill of Rights Handbook $4^{\text {th }}$ ed (Juta Lansdowne 2001)

Dugard International law 28

Dugard J International law: a South African approach $2^{\text {nd }}$ ed (Juta Kenwyn 2000)

Eide "Right to an adequate standard of living"

Eide $A$ "The right to an adequate standard of living, including the right to food" in Eide A, Krause C and Rosas A (eds) Economic, social and cultural rights (M Nijhoff Dordrecht 1995)

Erasmus "Limitations and suspension" 629

Erasmus G "Limitations and suspension" in Van Wyk D et al (eds) Rights and constitutionalism: the new South African legal order (Juta Kenwyn 1994) 629

Glazewski "New water law" 531-537

Glazewski J "New water law and the environment" in Environmental Law in South Africa (Butterworths Durban 2000) 531-537 
Jansen van Rensburg "Constitutional values and socio-economic rights" 3 Jansen van Rensburg $L$ "Constitutional values and socio-economic rights with reference to the right to access to social security" Congress of the Society of Law Teachers of Southern Africa Vista University Bloemfontein 20 January 1999

Jansen van Rensburg 1999 De Jure 294

Jansen van Rensburg L " Grondwetlike voorskrifte en die reg op toegang tot sosiale sekerheid" 1999 (1) De Jure 289

Klug 1997 HRCLJ 5- 6

Klug $\mathrm{H}$ "Water law reform under the new Constitution" 1997 HRCLJ 5- 6

Liebenberg "Socio-economic rights" 41-44

Liebenberg S "Socio-economic rights" in M Chaskalson et al (eds)

Constitutional Law of South Africa (Juta Kenwyn 1996) 41-44

Mandela Bill of Rights for a democratic South Africa

Mandela N A Bill of Rights for a democratic South Africa ANC Bill of Rights Conference CDS 199112

Samuel Fundamental social rights 316

Samuel L Fundamental Social Rights: case law of the European Social

Charter Council of Europe 1997 (Strasbourg Council of Europe 1997)

The Working for Water Programme 1998

SOUTH AFRICA (Republic) Department of Water Affairs and Forestry The

Working for Water Programme: annual report 1997/98 (Pretoria 1998)

Urban Morgan Institute for Human Rights

Urban Morgan Institute for Human Rights "Maastricht Guidelines on

Violation of Economic Social and Cultural Rights" 1998 (20) Human Rights

Quarterly 691 
White paper on a national water policy for South Africa 1997

SOUTH AFRICA (Republic) Department of Water Affairs and Forestry

White paper on a national water policy for South Africa (Pretoria 1997)

White Paper on Water Supply and Sanitation Policy 1994

SOUTH AFRICA (Republic) Department of Water Affairs and Forestry

White Paper on Water Supply and Sanitation Policy (Cape Town 1994)

\section{Register of legislation}

Constitution of the Republic of South Africa 1996

Constitution of the Republic of South Africa 200 of 1993

Extension of Security of Tenure Act 62 of 1997

Government Gazette 22355 R7079 8 June 2001

Land Reform (Labour Tenants) Act 3 of 1996

Local Government: Municipal Systems Act 32 of 2000

Municipal Systems Act 32 of 2000

National Water Act 36 of 1998

Procl R95 Government Gazette 1926916 September 1998

Water Act 54 of 1956

Water Services Act 108 of 1997

\section{Treaties and other international sources}

Additional Protocols 1977

African Charter on Human Peoples' Rights 1981

African Charter on the Rights and Welfare of the Child 1990

African Commission on Human and Peoples' Rights $15^{\text {th }}$ Annual Activity Report

African Commission on Human and Peoples' Rights $9^{\text {th }}$ Annual Activity Report

Agenda 211992

American Convention of Human Rights in the Area of Economic, Social and

Cultural Rights 1988

Convention on the Elimination of all forms of Discrimination Against Women 1979 
Dublin Statement on Water and Sustainable Development 1992

European Social Charter

International Conference on Population and Development Programme of Action 1994

International Covenant in Economic, Social and Cultural Rights 1996

Maastricht Guidelines on Violation of Economic Social and Cultural Rights 1997

Protocol to the African Charter on the Rights of Women in Africa 2003

The Convention of the Rights of the Child 1995

UN Committee on Economics, Social and Cultural Rights, General Comment 3 (1990) UN Doc HRI/Gen1/Rev 11994

UN Principles of Older Persons 1991

UN Water Conference Preamble to the Mar del Plata Declaration 1977

\section{Register of cases}

Certification of the Constitution of the Republic of South Africa 199619964 SA 744 (CC)

Free Legal Assistance Group, Lawyers' Committee for Human Rights, Union Interafricaine des Droits de l'Homme, Les Témoins de Jehova v Zaïre ACHPR Comm No 25/89, 47/90, 56/91, 100/93 (1995)

Government of the Republic of South Africa and Others $v$ Grootboom and Others 200011 BCLR 1169 (CC)

Grootboom and Others $v$ Oostenberg Municipality and Others 20003 BCLR 277 (C)

Manqele v Durban Transitional Metropolitan Council 20026 SA 423 (D)

Resident of Bon Vista Mansions v Southern Metropolitan Local Council 20026 BCLR 625 (W)

S v Makwanyane and Another 19956 BCLR 665 (CC)

$S$ v Zuma 19954 BCLR 401 (CC)

SERAC and CESR v Nigeria ACHPR Comm No 155/96

Soobramoney v Minister of Health (KwaZulu-Natal) 19981 SA 765 (CC) 


\section{Register of Internet resources}

Council of Europe http://www.asil.org/ilib/ilib0413.htm 23 Mar

Council of Europe (Committee of Ministers) Recommendation On the European Charter on Water Resources Rec (2001) 1417 October 2001

[Found on Internet] http://www.asil.org/ilib/ilib0413.htm accessed on the 2303-2005 [Date of use 23 Mar 2005]

DWAF http://www.dwaf.gov.za/freebasicwater/ 23 Mar

SOUTH AFRICA (Republic) Department of Water Affairs and Forestry Free

Basic Water Policy [Found on Internet]

http://www.dwaf.gov.za/freebasicwater/ [Date of use 23 Mar 2005]

SAHRC http://www.sahrc.org.za/4th esr chap 9.pdf 1 Feb

South African Human Rights Commission $4^{\text {th }}$ Economic and Social Rights

Report 2000/2002 [Found on Internet]

http://www.sahrc.org.za/4th esr chap 9.pdf [Date of use 1 Feb 2005]

SAHRC http://www.sahrc.org.za/socio economic report main.PDF 6 Jan

South African Human Rights Commission 1999 1st Economic \& Social

Rights Report: Baseline Information 1997-1998 [Found on Internet]

http://www.sahrc.org.za/socio economic report main.PDF [Date of use 26 Jan 2005]

\section{List of abbreviations}

ACHPR African Commission on Human and Peoples' Rights

CEDAW Convention on the Elimination of all forms of Discrimination Against Women

DWAF Department of Water Affairs and Forestry

FBW Free Basic Water

SAHRC South African Human Rights Commission 